\title{
ANALYSIS OF RESPIRED AMPHIBOLE FIBERS (ASBESTOS AND NON-ASBESTOS CLASSIFIED): DISCRIMINATION BETWEEN NATURAL AND ANTHROPOGENIC SOURCES USING SENTINEL ANIMALS
}

\section{This is the author's manuscript}

Original Citation:

\section{Availability:}

This version is available http://hdl.handle.net/2318/1612893

since 2018-06-14T15:14:30Z

Published version:

DOI:10.1007/s11869-016-0448-6

Terms of use:

Open Access

Anyone can freely access the full text of works made available as "Open Access". Works made available under a Creative Commons license can be used according to the terms and conditions of said license. Use of all other works requires consent of the right holder (author or publisher) if not exempted from copyright protection by the applicable law. 
This is the author's final version of the contribution published as:

Capella, Silvana; Fornero, Elisa; Bellis, Donata; Belluso, Elena. ANALYSIS OF RESPIRED AMPHIBOLE FIBERS (ASBESTOS AND NON-ASBESTOS CLASSIFIED): DISCRIMINATION BETWEEN NATURAL AND ANTHROPOGENIC SOURCES USING SENTINEL ANIMALS. AIR QUALITY, ATMOSPHERE \& HEALTH. 10 pp: 533-542. DOI: 10.1007/s11869-016-0448-6 AIRQ-D-16-00179.1

When citing, please refer to the published version.

Link to this full text:

http://hdl.handle.net/2318/1612893 


\title{
ANALYSIS OF RESPIRED AMPHIBOLE FIBERS (ASBESTOS AND NON-ASBESTOS CLASSIFIED): DISCRIMINATION BETWEEN NATURAL AND ANTHROPOGENIC SOURCES USING SENTINEL ANIMALS
}

\author{
Silvana Capella a ${ }^{\text {, Elisa Fornero }}{ }^{\text {b }}$, Donata Bellis ${ }^{\mathrm{c}}$, Elena Belluso ${ }^{\text {a,c }}$

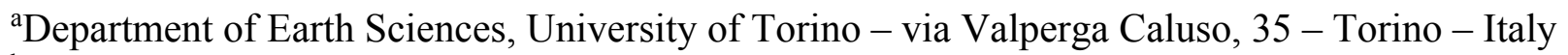 \\ ${ }^{b}$ Department of Sciences and Technological Innovation, University of Piemonte Orientale - via \\ Teresa Michel, 11 - Alessandria - Italy \\ ${ }^{\mathrm{c} D e p a r t m e n t}$ of Services, Pathological Anatomy - ASLTO1 - Martini Hospital - via Tofane, 71 - \\ Torino - Italy \\ ${ }^{\mathrm{d} I n s t i t u t e}$ of Geosciences and Earth Resources, CNR, Unit of Torino - via Valperga Caluso, 35 - \\ Torino - Italy
}

corresponding author: Silvana Capella, silvana.capella@unito.it, via Valperga Caluso, 35 - Torino Italy - tel. (+39) 0116705121

\begin{abstract}
To evaluate the degree of exposure and to distinguish the contributions of respirable amphibole fibers (both asbestos and non-asbestos) from natural and anthropogenic sources, we investigated their burden in the lungs of sentinel animals.

Lung samples of sentinel animals are more easily and continuously available in comparison to humans, and are not affected by human variables such as occupational exposure and smoking habit. Fiber identification and quantification have been performed using a scanning electron microscope (SEM) with an energy dispersive spectrometer (EDS).

Results for detected amphibole fibers (both asbestos and non-asbestos) were obtained from six studied areas in Northwest Italy (the Piedmont Region) and correlated to lithological and urbanization data. Detected amphibole fibers species have been classified as asbestos minerals occur naturally (NOA) or to anthropogenically sourced asbestos (ASA).

This pilot study is a potentially useful tool for the evaluation of the distribution and sources of respirable inorganic fibers. The model should be applicable in any areas where lithological and anthropogenic characteristics are known.
\end{abstract}

Keywords: asbestos; amphibole fibers; sentinel animals; air pollution; environmental exposure; SEM-EDS 


\section{Introduction}

Amphiboles are a very common and abundant group of minerals, but they are structurally and chemically quite complicated and therefore their classification has been a work in progress for a long time. This work culminated in a classification scheme, that has been initially described by Leake (1978), later modified by Leake et al. (1997, 2003), and then revised by Hawthorne et al. (2012). In brief, amphiboles are hydroxylated silicates containing a wide variety of cations and anions.

Amphiboles occur naturally in rocks, both igneous and metamorphic (e.g., Martin 2007; Schumacher 2007). They commonly occur with both prismatic and flattened morphologies and the crystals may have length to width ratios greater than $3: 1$, corresponding to the mineralogical definition of a fiber (Centeno 2005).

Five amphiboles are classified as asbestos by WHO when they occur in a respirable size with certain dimensions (length $>5 \mu \mathrm{m}$, width $<3 \mu \mathrm{m}$, aspect ratio greater than or equal to $\geq 3: 1$ (WHO 1997). They are tremolite asbestos, actinolite asbestos, grunerite asbestos (or amosite), anthophyllite asbestos, and asbestiform riebeckite (or crocidolite), according to the international nomenclature. These minerals have distinct physical and chemical proprieties such as thermal and chemical resistance, flexibility, and tensile strength. In the past, these different properties have determined how crocidolite and amosite and, to a lesser extent anthophyllite asbestos, have been used commercially. Their use was especially common in the building trades as manufactured asbestos containing materials (ACM). Tremolite asbestos and actinolite asbestos have not been used commercially in ACM to any significant extent but they do occur abundantly in several kinds of rocks worldwide mined for ornamental stones and railway ballast. They are particularly abundant either in serpentinites where they occur as the main mineral in rock veins or as accessory minerals along with other commodities that are mined such as chrysotile, talc, and vermiculite (Roggli et al. 2002). Therefore, owing their commercial use or natural presence in rocks, amphibole asbestos are widespread geographically, even where they have been banned.

Amphibole asbestos are continuously released into the air, water, and soils from natural sources (i.e. naturally occurring asbestos: NOA) and anthropogenic sources (anthropogenically sourced asbestos: ASA). Both natural events (i.e. weathering) as well as human activity (such as building or road construction) may cause the release of these fibers into the atmosphere and increase their background levels in the environment.

In most countries, only some fibrous amphiboles species exist as NOA, while others occur only as ASA. As an example, in Italy tremolite asbestos and actinolite asbestos and other fibrous amphiboles such as edenite are present only in NOA. On the other hand, amosite and crocidolite come only from 
ASA (as ACM) because they are not present in the local rocks. Therefore, in Italy as elsewhere, species of fibrous mineral dispersed in air depend on types of existing sources of both NOA and ASA. Owing to their size, these fibers can enter into the respiratory system. If respired in large amounts, for a long period, they can have toxic effects (Dodson et al. 2003).

Correlation between high dose exposures, typically in occupational or para-occupational exposure, and specific asbestos-related diseases (e.g. asbestosis, mesothelioma and pleural plaques) has been known for many years. Cases of mesothelioma have also been reported in workers occupationally exposed to low doses of some amphiboles non-asbestos classified, such as asbestiform winchite and richterite intergrown with vermiculite ore mined and milled at Libby (Montana-USA) from 1920 to 1990 (Meerker et al. 2003).

Even environmental asbestos amphiboles contamination in the neighborhood of asbestos sources may entail risk of mesothelioma or pleural calcifications. Cases have been reported from countries including Greece (Constantopolus et al. 1987), Turkey (Yazicioglu et al. 1980) and, New Caledonia (Luce et al. 2000), where the local rock deposits containing asbestos amphibole fibers have been used for whitewashing and plastering dwellings or for road paving. Therefore, in such situations, the population has been subjected to anthropogenic environmental exposure. That is, while the exposure sources are from NOA, the exposure itself is from human activity.

Other than asbestos-related deseases, a significant increase of mortality from mesothelioma is also observed in areas where asbestos does not occur. Many investigations have revealed a correlation between mesothelioma and anthropogenic and natural environment exposure to fibers not classified as asbestos. Examples include the case of fluoro-edenite amphibole fibers in northeastern Sicily (Southern Italy) (Gianfagna et al. 2003), ) and erionite zeolite fibers in Cappadocia, Turkey (Baris et al. 1987).

At present, no measurements concerning the relative amounts of asbestos (and amphiboles asbestos in particular) released by anthropogenic versus natural processes are available (e.g. Kakooei et al. 2009) and it is not possible to define a lowest exposure threshold below which an increased risk of some deleterious health effects would not occur (Hillerdal 1999), as for every air pollutant (McClellan 2012). The effects on health do not depend only on the quantity of the asbestos fibers respired but also on the mechanisms by which these fibers cause diseases.

As stated by Roggli (1990), the examination of fiber burdens in biological material is useful for assessing the risk of subsequent disease. One method for investigating potential human exposure to environmental inorganic contaminants, when exposure is continuous for a long period at low dosage levels, is to analyze the lung fiber burden (expressed as respirable fibrous mineral fraction) in animals. 
This approach has been used in a number of studies (De Nardo et al. 2004; Dumortier et al. 2002; Fornero et al. 2009).

A non-experimental animal model (called "sentinel animal") (NRC 1991) is used as an alternative to a human-based model. The sentinel animal model is useful because some complicating factors such as occupational and para-occupational exposure as well as the habit of smoking do not occur in animals. Additionally, animal lung samples are more easily available in the large numbers necessary for sound statistical studies. When animals are destined for a slaughterhouse, the continuity of sample availability is also advantageous. Besides that, the great availability of sentinel animals offers the possibility of expanding the understanding of and response to environmental health concerns.

Mineral fibers in lungs (and in other biological materials) may be identified and quantified using scanning or transmission electron microscopy (SEM or TEM) associated with energy dispersive spectrometry (EDS).

Our aim was to demonstrate that the fiber burden assessment from the lungs of sentinel animals is useful both to identify which kinds of respirable amphibole fibers (both asbestos and non-asbestos) were airborne and to supply information for the identification of sources (NOA or ASA).

Since there are multiple and often contradictory hypotheses on the health effects of fibers of different lengths (e.g. Aust et al. 2011; Roggli 2015), we additionally measured shorter fibers with lengths $<5$ $\mu \mathrm{m}$ from the lungs to improve our knowledge of all respired fibers.

With this intent, we selected six areas of Northwestern Italy, in the Piedmont region, to conduct the study where both NOA (geomorphological and lithological) and ASA (industrial and other manmade) sources exist and are well known.

In Piedmont previous investigation revealed that, the following asbestos and asbestiform minerals are diffused in local rocks (in decreasing order of finding frequency): chrysotile, antigorite, tremolite, diopside, carlosturanite, forsterite, balangeroite, sepiolite, brugnatellite, and brucite (Belluso et al. 1997; Arpa 2008). Regarding the six areas of interest, rock outcrops of ophiolites, marbles, dolostones and limestones, gneisses, amphibolitic lenses, plutonic rocks more or less metamorphosed (Figure1: numbers 10 to 15 ) contain fibrous minerals, including some species of amphiboles (e.g. tremolite and actinolite), which can potentially be released into the atmosphere. These are variously distributed in air depending on geomorphological and lithological characteristics (Regione Piemonte 2005).

About the ACM, a recent map published by local environmental protection agency shows the location of the asbestos contained in building roofs, the most diffused and abundant kind of ACM in this region (Arpa, 2011). 


\section{Materials and methods}

In collaboration with veterinarians of the Local Health Unit, we collected 78 lung samples from animals that lived in six different areas (30 living sites) of Northwestern Italy, in Piedmont. The different species and their provenance were: 26 cows from Susa Valley, Turin (SV group); 18 cows from Lanzo Valleys, Turin (LV group); 7 cows from Sesia Valley, Vercelli (VC group); 6 wild animals (3 deer, 2 chamois, 1 wild boar) from Varaita Valley, Cuneo (VV group); and 21 cows from Asti (AT group). From the administrative point of view, SV is divided into upper SV (USV) and lower SV (LSV). USV and LSV have anthropization degrees that are respectively low and high, according to urbanization, industrial activities, vehicular traffic degree, and the road network development. The location of these six areas is shown in Figure 1.

Fibrous tremolite and actinolite are abundant. They are the most widely distributed amphiboles in the $\mathrm{SV}$ and LV areas; their presence is modest in VV and scarce in VC. Anthophyllite asbestos is only rarely present in small amounts (Belluso et al. 1994). Crocidolite and amosite are not contained in the rocks of these areas as in the other Italian regions. As far as the authors (Piccoli et al. 2007) have determined, only the non-fibrous variety of edenite amphibole is found (sporadically) in rocks of the Piedmont.

The AT area was chosen as control area because the rock outcrops there do not contain fibrous amphiboles. The animals that lived there were therefore considered a control group for the health investigations.

For each sample, $250 \mathrm{mg}$ of lung tissue have been chemically digested by $\mathrm{NaClO}$ at room temperature to eliminate the organic fraction. The inorganic material has then been recovered by filtering the suspension on a mixed cellulose esters filter with a diameter of $25 \mathrm{~mm}$ and porosity of $0.45 \mu \mathrm{m}$. Each membrane was investigated by SEM (Cambridge S360, Carl Zeiss Microscopy GmbH, Carl Zeiss Promenade 10, 07745 Jena, Germany) using back-scattered electron images in addition to secondary electron images. Only particles corresponding to the mineralogical definition of a fiber (i.e. having a length/width. ratio $>3: 1$ ) have been considered. Their dimensions have been determined by SEM and chemical composition were measured by EDS (EDS Inca Energy 200 equipped with INCA Xact SDD detector). Detailed instrumental conditions and measurement techniques have been described elsewhere (Belluso et al. 2006).

To obtain the dry weight conversion factor required to adjust the number of recovered fibers to one gram of dry weight (fibers per gram dry weight; ff/gdw) according to the international standard (De Vuyst et al. 1998), 2.5 grams of tissue from each sample were dehydrated in an oven at $60^{\circ} \mathrm{C}$ for 72 hours. 
The fibers recovered have been identified by their EDS spectra and only those recognized as amphiboles were investigated to distinguish between asbestos and non-asbestos fibers.

We classified the selected amphiboles as respirable (Rff) and shorter fibers (sff) according to their dimensions. Rff fibers were defined as having lengths $>5 \mu \mathrm{m}$ and widths $<3 \mu \mathrm{m}$ (the size of the regulated asbestos fibers under Directive 2003/18/EC; WHO 1997) and sff fibers had lengths $<5 \mu \mathrm{m}$ and widths $<3 \mu \mathrm{m}$ (non-asbestos classified).

While short and thin fibres may also play a role in asbestos pathogenesis (Aust et al. 2011; Adib et al. 2013) the current consensus is that they do not (ATSDR 2002; Roggli 2015).

On the basis of both geological knowledge (Figure 1) and location of ACM data (Arpa Piemonte 2011) relative to the areas where the animals lived, the fibers detected in lung samples were classified as from NOA or ASA.

With the exception of Asti, chosen as control area, all the other areas consist of outcropping or suboutcropping rocks that potentially release amphiboles fibers (NOA - indicated by number 10, 11, 14 in the legend of Figure 1).

The VS, VL, VC areas are free from agricultural work due to the few soils available. In VV only a very small area is involved in agricultural works; but this is very far from the one where the collected animals lived. Therefore, to our investigation we considered VV area free from agricultural works (Regione Piemonte, 2013).

Regarding human activity in the studied areas, we adopted the four grades indicated in the explicative notes of the Piedmont region agriculture and forest landscape map (Regione Piemonte 2005); a) high, with medium to high human population, medium to intensive agricultural activity, presence of highways; b) moderate, with medium human population and medium agricultural activity; c) low, with sparse human population and limited agricultural activity; d) very low, with very sparse human population and no agricultural activity.

The areas with ASA are those where the presence of ACM represented by built roofs is highlighted in the map of Regional Agency for the Protection of the Environment (ARPA 2011) obtained by satellite images. These kinds of roofs are sources of asbestos amphiboles (crocidolite and amosite) abundant release.

The presence of ACM inside the buildings is not currently mapped, but it is not so important from the point of view of release of amphiboles in air because these materials are sources of very small amount of fibers that can be aerodispersed because they are not exposed to weathering. 


\section{Results and Discussion}

The 78 lung tissue samples were grouped according to the six areas of the Piedmont where the animals lived (SV, sub-divided into USV and LSV, LV, VV, VC and AT). The data are summarized in Table 1. For each area, the number of examined animals, its degree of human activity, the average concentration of total inorganic fibers, the average concentration of amphibole fibers, and their percentage with respect to total inorganic fibers are listed.

The total inorganic fiber amount (including amphiboles) is higher in LSV; with respect to LSV it is roughly two-thirds in USV and half in LV and.

The amount in these three areas is higher than in AT (the control group), and in VV and VC areas; the last two have similar values. The AT area has the lowest total concentration, as expected.

The total amount of inorganic fibers detected in LSV is two orders of magnitude more than that in AT. The amounts present in USV, LV, VV and VC are still much greater than in AT, but only by one order of magnitude.

Considering only amphibole fibers, in LSV, USV and LV their amounts are two orders of magnitude greater than in AT, whereas in VV and VC their amounts are one order of magnitude greater than in AT.

Considering the percentage of amphibole fibers as a proportion of the total inorganic fiber assemblage, the proportion in LSV is the highest we recorded and roughly twice that of USV and LV, that are similar one each other. The percentage in VC is lower, and the one in VV and AT are similar to each other as well as the lowest we recorded.

Amphibole fibers were detected in all the groups of animal samples examined for each area although not in every animal (Table 2). In all groups, the percentage of Rff is higher than that of sff.

We differentiated the amphibole fibers in terms of their chemical composition, size and source. We found that three kinds of amphiboles came from NOA, specifically tremolite/actinolite asbestos, tremolite/actinolite and edenite. Crocidolite, amosite and grunerite (non-asbestos) have ASA sources (Figure 3).

The mineral species tremolite and actinolite are hereafter considered one group because the chemical data alone do not allow us to discriminate the two mineralogical species (indicated tremolite/actinolite).

Tremolite/actinolite asbestos is the most abundant group of fibers and the only one present in all groups of animal samples examined in each area.

The average amount of tremolite/actinolite asbestos detected in LSV is the highest and its value is about 3.5 times higher than USV and LV (these are similar to each other). The amounts in USV and 
LV are two orders of magnitude more abundant than in AT. The amounts in VV and VC are one order of magnitude more abundant than in AT.

These data reflect the presence of rock outcrop types containing this kind of asbestos (NOA) and their airborne extension in the examined areas (Arpa Piemonte 2011).

Tremolite/actinolite fibers (not classified as asbestos because they are sff) were detected in LSV (the highest value), USV, LV and VC; the amounts were one order of magnitude less than Rff in the corresponding areas.

The last type of amphibole fibers from NOA was edenite (solely as Rff) present only in two out of five areas (USV and LV); the amounts are low.

Three kinds of amphiboles were determined to come from ASA: crocidolite in LSV, amosite in LSV and LV, and grunerite (sff and therefore by definition non-asbestos) in LV. We classify them as ASA because no rock formations in the examined areas are known to contain such minerals.

The amount of non-asbestos grunerite is low; the crocidolite and amosite concentrations are one order of magnitude higher.

Total amphibole fiber from NOA $(81,301 \mathrm{ff} / \mathrm{gdw})$ is much more abundant than that from ASA $(4,449$ $\mathrm{ff} / \mathrm{gdw})$ in these areas.

An inspection of the living sites (Figure 2) shows that the two areas with the highest amount of tremolite/actinolite asbestos are at Mompantero (over 125,000 ff/gdw) and Venaus (over 80,000 $\mathrm{ff} / \mathrm{gdw}$ ), both in LSV. Only a little more than 40,000 ff/gdw have been detected in Salbertrand (USV) and Groscavallo (LV), and about 32,000 ff/gdw in Susa and Meana (LSV). The $20 \%$ of the total area where the average concentration of tremolite/actinolite asbestos is more than $18,000 \mathrm{ff} / \mathrm{gdw}$ is in USV, LSV and LV; the $16,7 \%$ is in USV and LSV. In the rest of the sites (80\%), the average concentrations are below $18,000 \mathrm{ff} / \mathrm{gdw}$.

Concentrations of inorganic fibers in the animal lung samples are not directly correlated to the degree of human use of each examined area. The same is true for concentrations of amphibole fibers (Table 1).

In LSV, USV and LV samples, amphibole fibers content is prominent due to their very high contribution from NOA as compared to ASA (Table 2). This is not likely related to their biopersistence because the biopersistence of tremolite/actinolite asbestos and crocidolite is similar (Hobbs 2003).

Only in LSV and LV (Table 2) we detected crocidolite, amosite, and non-asbestos grunerite. All of them came from ASA, areas having different degrees of human activity (Table 1). Coded human 
activity degree may not be a satisfactory parameter because illicit dumping of ACM waste may be present, as found in several other Italian areas (e.g., Comba et al. 2006).

A correlation between NOA tremolite/actinolite (both asbestos and non-asbestos) detected in lung samples and serpentine rock outcrops (where the two amphiboles are abundant) was also found. The average concentration of these two mineral groups is correlated with the abundance of serpentinite rocks in the USV, LSV, and LV (Figure 2) that are a significant portion of the outcropping rocks. Such rocks, bearing tremolite/actinolite fibers, are more widespread in LSV than in USV and LV (Belluso et al. 1994; Groppo and Compagnoni 2007).

The statistical comparison between the respired fibrous amphiboles concentration and the surface area of fibrous amphiboles bearing outcropping rocks for the six assessed areas will be the target of a further paper.

In spite of that, our results show that the average concentration of total amphibole fibers (Table1) detected in LSV animal lungs is $0.51 \times 10^{5} \mathrm{ff} / \mathrm{gdw}$, only a little less than the average $1 \times 10^{5} \mathrm{ff} / \mathrm{gdw}$ reported for humans who suffered significant occupational exposure to asbestos (DeVuyst et al. 1998; Tossavainen 1997)

The presence of asbestos tremolite/actinolite in AT, an area with no rocks bearing this kind of NOA fiber, could be attributed to fiber dispersion from railway ballast. Railways in Piedmont were commonly built with blocks of serpentinitic rocks. The very low amount of such fibers in animal lungs is consistent with the moderate quantity in the source.

\section{Conclusions}

The present investigation was based on an interdisciplinary collaboration between mineralogists and animal pathologists.

It allowed us to assess, in six areas of Northwestern Italy, in the Piedmont region, with specific geomorphological and lithological characteristics, exposure to respirable fibrous amphibole using sentinel animals.

The mineralogical investigation allowed us to detect different kinds of amphibole fibers, both asbestos (i.e. tremolite/actinolite asbestos, amosite, and crocidolite) and non-asbestos (i.e. tremolite/actinolite, fibrous edenite, and non-asbestiform fibrous grunerite).

Obviously, the respiratory system anatomy and the clearance mechanisms are different among the various animal species and humans; therefore, lung fiber concentrations may not be directly comparable. Exposure time would also differ. However, the data do provide information on the 
rough magnitude; in other words, lowest and highest fiber burden in lung are relative to lowest and highest air-dispersed fiber concentration respectively.

Such results should be interpreted in the light of the geological and human activity data (including $\mathrm{ACM}$ ) and show, overall, a qualitative correlation with presence of both natural and human activity dispersion sources.

In the LSV area the concentration of respired amphibole fibers is highest, and their amount is distant from the threshold of $1 \times 10^{5} \mathrm{ff} / \mathrm{gdw}$ considered to be the indicator of human occupational exposure to asbestos (DeVuyst et al. 1998; Tossavainen 1997), being about the half.

Since only fibers that reach the lungs and there remain, or those that hence migrate towards other organs (i.e. by vascular and lymphatic systems: Englert et al. 2014) can cause deleterious health effects (fibers classified as respirable), in the opinion of the authors, it is more important to determine both the kind and the amount of fibers that lodge in the lungs rather than just knowing their abundance in the air.

Finally the use of sentinel animals instead of humans for this monitoring is particularly valuable for three reasons: a) they are readily available (at least certain species); b) they represent dynamic fiber samples within limited areas as well as acting as accumulators; c) they are not affected by confounding factors (such as occupational exposures). Furthermore, the collection of airborne fibers by air-sampler instead of using sentinel animals is not as useful because it is limited both temporally and, above all, spatially.

This study suggests a method to identify areas where previously unknown sources of amphibole asbestos exposures may be present and where further investigations may be performed.

In general, this method allows determination whether in certain life environments and for a determined time, respirable and potentially harmful inorganic substances are present, and if there is an unidentified pollution situation.

This method can be replicated elsewhere; the knowledge of such kinds of results would potentially allow stakeholders to evaluate the possible air-dispersion of certain pollutants (e.g. when asbestoscontaining materials and rocks are handled), and to carry out programs to reduce or eliminate dispersion. 


\section{Acknowledgements}

This study was financially supported by INRM (Istituto Nazionale per la Ricerca Scientifica e Tecnologica sulla Montagna). Assessorato all’Ambiente della Regione Piemonte and Ricerca Sanitaria Finalizzata.

The authors wish to thanks Dr. Giordano for map preparation.

\section{FIGURE CAPTIONS}

Fig. 1 Lithological, landform and road map of Piedmont Region (adaptation from Regione Piemonte, 2012) From NE to SW, the five investigated areas (containing NOA) are bounded and discriminated with different kind of continous lines (from top to bottom): oblique right to left lines indicate Sesia Valley area (VC); oblique left to right lines indicate Lanzo Valley area (LV); vertical lines indicate Susa Valley area (USV and LVS); square forming double lines indicate Varaita Valley area (VV). Asti area (AT) has been used as control because free from NOA. As reference, the region chief town (Torino) and three province capitals are indicated

Regione Piemonte (2013) Arpa Piemonte - Carta Litologica del Piemonte. http://webgis.arpa.piemonte.it/free/services/geologia_e_dissesto/Carta_litologica/MapServer/WMSServer?

1) Terraced, recent and present day fluvial deposits, with subordinate glaciofluvial deposits

2) Complexes of morainic ridges and intermorainic depressions

3) Sands or silty-clayey coastal sediments; sandy, sandy-gravelly or loamy-clayey alluvial deposits

4) Sands with sandstones lenses

5) Pelites, clayey marls, marls, gypsarenites and evaporites

6) Marls with interbedded sand or sandstone levels

7) Marly siltstones, with locally interbedded sandstone levels or conglomerate lenses

8) Sandstone and conglomerate, with interbedded marls and sandy marls

9) Clays, marls, limestones and chaotic clayey complex

10) Ophiolites with various grade metamorphism (bearing that contain serpentinitic rocks too)

11) Quartzites, schists, marbles, phyllites

12) Crystalline dolostones and limestones, dolomitic limestones, sandy-marly limestones

13) Micaschists and gneisses, with subordinate phyllites, quartzites, eclogites, schists and marbles

14) Gneisses and migmatites, with subordinate schists, porphyries and amphibolitic lenses

15) Plutonic and volcanic Alpine or Pre-Alpine rocks

Fig. 2 Concentrations of tremolite/actinolite asbestos (ff/gdw) in lung samples of animals from 30 sampling sites (USV; LSV; LV; VC; VV; AT)

Fig. 3 SEM images (2000M) and relative EDS spectra of tremolite/actinolite asbesto (a), edenite ( $\mathrm{Na}$ and $\mathrm{Cl}$ represent a residue of chemical digestion) (b), crocidolite ( $\mathrm{Cl}$ and a portion of $\mathrm{Na}$, represent a residue of chemical digestion) (c), and amosite (d) detected in lung samples of sentinel animals 


\section{References}

Adib G, Labrèche F, De Guire L, Dion C, Dufresne AD (2013) Short, fine and WHO asbestos fibers in the lungs of Quebec workers with an asbestos-related disease. Am J Ind Med 56:10011014.

Arpa Piemonte (2008) Amianto naturale in Piemonte.

https://www.arpa.piemonte.gov.it/pubblicazioni-2/pubblicazioni-anno2008/pdfamiantonaturale.pdf

Arpa Piemonte (2011) Mappatura delle coperture in cemento amianto. http://webgis.arpa.piemonte.it/w-metadoc/tumbnail

ATSDR (Agency for Toxic Substances and Disease Registry) (2002) Report on the Expert Panel on Health Effects of Asbestos and Synthetic Vitreous Fibers: The Influence of Fiber Length. New York, NY: Expert Panel on Health Effects of Asbestos and Synthetic Vitreous Fibers; October 29$30,2002$.

Aust AE, Cook PM, Dodson RF (2011) Morphological and chemical mechanisms ofelongated mineral particle toxicities. J Toxicol Environ Health B Crit Rev 14:40-75.

Baris I, Simonato L, Artvinli M, Pooley F, Saracci R, Skidmore J et al (1987) Epidemiological and environmental evidence of the health effects of exposure to erionite fibres: a four-year study in the Cappadocian region of Turkey. Int J Cancer 39:10-7.

Belluso E, Compagnoni R, Ferraris G (1994) Occurrence of asbestiform minerals in the serpentinites of the Piemonte Zone, Western Alps. Giornata di studio in ricordo del Prof. S. Zucchetti, Politecnico di Torino 57-66.

Belluso E, Ferraris G, Alberico A (1997) Amianto, la componente ambientale: dove, quali e come sono gli amianti nelle Alpi? In: L'amianto: dall'ambiente di lavoro all'ambiente di vita. Nuovi indicatori per futuri effetti. Fondazione S. Maugeri, IRCCS, Pavia - I documeti 12:167-174. 
Belluso E, Bellis D, Fornero E, Capella S, Ferraris G, Coverlizza S (2006) Assessment of inorganic fiber burden in biological samples by scanning electron microscopy-energy dispersive spectroscopy. Microchim Acta 155:95-100.

Centeno JA, Mullick FG, Ishak KG, Franks TJ, Burke AP (2005) Environmental Pathology. In: Selinus O., Alloway B., Centeno J.A., Finkelman R.B., Fuge R., Lindh U., Smedley P. (eds), Essentials of Medical Geology. Burlington, USA, pp 563-594.

Comba P, Bianchi F, Fazzo L, Martina L, Menegozzo M, Minichelli F, Mitis F, Musmeci L, Pizzuti R, Santoro M, Trinca S, Martuzzi M (2006) Cancer Mortality in an Area of Campania (Italy) Characterized by Multiple Toxic Dumping Sites. Ann NY Acad Sci 1076:49-461.

Constantopoulos SH, Saratzis N, Kontogiannis D, Karantanas A, Goudevenos JA, Katsiotis, P (1987) Tremolite whitewashing and pleural calcifications. Chest 92:709-712.

De Nardo P, Bruni B, Paletti L, Pasetto R, Siriani B (2004) Pulmunary fibre burden in sheep living in the Biancavilla area (Sicily): preliminary results. Sci Total Environ 325:51-58.

De Vuyst P, Karjalainen A, Dumotier P, Pairon JC, Monsò E, Brochard P, Teschler H, Tossavainen A, Gibbs A (1998) Guidelines for mineral fibre analyses in biological samples: report of the ERS Working Group. Eur Respir J 11:1416-1426.

Directive 2003/18/EC of the European Parliament and of the Council of 27 March 2003 Amending Council Directive 83/477/EEC on the protection of workers from the risks related to exposure to asbestos at work. Official Journal L97 of 15.4.2003, 48.

Dodson RF, Atkinson MA, Levin JL (2003) Asbestos fiber length as related to potential pathogenicity: a critical review. Am J Ind Med 44:291-297.

Dumortier P, Rey F, Viallant JR, Broucke I, Boutin C, De Vuyst P (2002) Chrysotile and tremolite asbestos fibres in the lungs and parietal pleura of Corsican goats. Occup Environ Med 59:643-646.

Englert JM, Kliment CR, Oury TD (2014) Experimental models of asbestos-related diseases. In: T.D. Oury, T.A. Sporn, V.L. Roggli (eds), Pathology of asbestos-associated diseases 215-251. 
Fornero E, Belluso E, Capella S, Bellis D (2009) Environmental exposure to asbestos and other inorganic fibres using animal lung model. Sci Total Environ 407:1010-1018.

Gianfagna A, Ballirano P, Bellatreccia F, Bruni B, Paoletti L, Oberti R (2003) Characterization of amphibole fibres linked to mesothelioma in the area of Biancavilla, Eastern Sicily, Italy. Mineral Mag 67: 1221-1229.

Groppo C, Compagnoni R (2007) Metamorphic veins from the serpentinites of the Piemonte Zone, western Alps, Italy: a review. Periodico di Mineralogia 76: 127-53.

Hawthorne FC, Oberti R, Harlow GE, Maresch WV, Martin RF, Schumacher JC, Welch MD (2012) Nomenclature of the amphibole supergroup. Am Mineral 97(11-12):2031-2048.

Hillerdal G (1999) Mesothelioma: cases associated with non-occupational and low dose exposure. Occup Environ Med 56:505-513.

Hobbs C (2003) Fiber Durability and Biopersistence - Assessment and Role in Asbestos Toxicology Asbestos Mechanisms of Toxicity Workshop, June 12-13, 2003 Chicago, Illinois.

Kakooei H, Yunesian M, Marioryad, Azam K (2009) Assessment of airborne asbestos fiber concentrations in urban area of Tehran, Iran. Air Quality Atmosphere \& Health 2:39-45.

Leake BE (1978) Nomenclature of amphiboles. Can Mineral 16:501-520.

Leake BE, Woolley AR, Arps CES, Birch WD, Gilbert MC, Grice JD, Hawthorne FC, Kato A, Kisch HJ, Krivovichev V G, Linthout K, Laird J, Mandarino JA, Maresch WV, Nickel EH, Rock NMS, Schumacher JC, Smith DC, Stephenson NCN, Ungaretti L, Whittaker EJW, Youzhi G (1997) Nomenclature of amphiboles: Report of the Subcommittee on Amphiboles of the International Mineralogical Association, Commission on New Minerals and Mineral Names. Can Mineral 35:219-246.

Leake BE, Woolley AR, Birch WD, Burke EAJ, Ferraris G, Grice JD, Hawthorne FC, Kisch HJ, Krivovichev VG, Schumacher JC, Stephenson NCN, Whittaker EJW (2003) Nomenclature of 
amphiboles: additions and revisions to the International Mineralogical Association's amphibole nomenclature. Can Mineral 41:1355-1370.

Luce D, Buge, I, Goldberg P, Goldberg M, Salomon C, Billon-Galland MA, Nicolau J, Quenel P, Fevotte J, Brochard P (2000) Environmental Exposure to Tremolite and Respiratory Cancer in New Caledonia: A Case-Control Study. Am J Epidemiol 151:259-265.

Martin RF (2007) Amphiboles in the igneus environment. In: J.J. Rosso (ED), Amphiboles: crystal chemistry, occurrence, and health issues. Rev Mineral Geochem 67:323-357.

McClellan R O (2012) Role of science and judgment in setting national ambient air quality standards: how low is low enough? Air Quality, Atmosphere \& Health 5:243-258.

Meerker GP, Bern AM, Brownfield IK, Lowers HA, Sutley SJ, Hoefen TM, Vance JS (2003) The composition and mineralogy of amphiboles from the Rainy Creek Complex, near Libby, Montana. Am Mineral 88:1955-1969.

NRC (National Research Council), Committee on Animals as Monitors of Environmental Health Hazards (1991) Animals as Sentinels of environmental health hazards. Washington, DC: National Academy Press 160.

Piccoli GC, Maletto G, Bosio P, Lombardo B (2007) Minerali del Piemonte e della Valle d'Aosta. Associazione Amici del Museo "F. Eusebio" Alba, (Cuneo) p 607.

Regione Piemonte (2005) Explanatory notes to agricultural and forest landscape map. http://www.regione.piemonte.it/agri/area_tecnico_scientifica/suoli/paesaggi/dwd/note.pdf" \t blank

Regione Piemonte (2013) http://www.regione.piemonte.it/agri/psr2014_20/dwd/vas/BozzaPSR_1305_2013.pdf).

Roggli VL (1990) Human disease consequences of fiber exposures: a review of human lung pathology and fiber burden data. Environ Health Persp 88:295-303.

Roggli VL, Vollmer RT, Butnor KJ, Sporin TA (2002) Tremolite and Mesothelioma. Ann Occup Hyg 46(5):447-453. 
Roggli VL (2015) The so-called short-fiber controversy: Literature review and critical analysis. Arch Pathol Lab Med 139:1052-1057.

Schumacher JC (2007) Metamorphic amphiboles: composition and coexistence. In: J.J. Rosso (Ed), Amphiboles: crystal chemistry, occurrence, and health issues. Rev Mineral Geochem 67:359416.

Tossavainen A (1997) Asbestos, asbestosis and cancer. The Helsinki criteria for diagnosis and attribution. Consensus Report Scand. J Work Environ Health 23:211-216.

WHO (1997) Asbestos and other natural mineral fibres. International Programme for Chemical Safety. In: Environmental Health Criteria, Geneva, Switzerland.

Yazicioglu S, Ilçaito R, Balci K, Sayli BS (1980) Plural calcifications, pleural mesotheliomaand bronchial cancers caused by tremolite dusts. Torax 35:564-569. 


\begin{tabular}{cc|c|cc}
\hline $\begin{array}{c}\text { Areas } \\
\text { (number } \\
\text { of examined } \\
\text { animals) }\end{array}$ & $\begin{array}{c}\text { Anthropization } \\
\text { degree }\end{array}$ & $\begin{array}{c}\text { Overall inorganic } \\
\text { fibers } \\
\text { (ff/gdw, average) }\end{array}$ & $\begin{array}{c}\text { Amphibole } \\
\text { fibers } \\
\text { (ff/gdw, } \\
\text { average) }\end{array}$ & $\begin{array}{c}\text { Amphibole } \\
\text { fibers I Overall } \\
\text { inorganic fibres } \\
\text { (\%) }\end{array}$ \\
\hline USV (12) & low & 78,808 & 16,031 & 20 \\
LSV (14) & high & 126,647 & 50,920 & 40 \\
LV (18) & $\begin{array}{c}\text { very low to } \\
\text { moderate }\end{array}$ & 56,541 & 16,028 & 28 \\
VV (6) & low & 15,277 & 1,122 & 7 \\
VC (7) & moderate & 11,317 & 1,587 & 14 \\
AT (21) & low & 2,928 & 136 & 5 \\
\hline
\end{tabular}

Tab. 1 Average concentration (ff/gdw) of overall inorganic fibers and amphibole fibers in relation to five different areas and their anthropization degree where animals lived. The amphibole fibers percentage on the overall inorganic fibers is also indicated 


\section{Amphibole fibers}

\begin{tabular}{|c|c|c|c|c|c|c|c|c|}
\hline \multirow{3}{*}{$\begin{array}{c}\text { Areas } \\
(\%)^{*}\end{array}$} & & & \multicolumn{3}{|c|}{ Ns } & \multicolumn{3}{|c|}{ As } \\
\hline & & & $\begin{array}{c}\text { tremolite/actinolite } \\
\text { asbestos } \\
\text { (ff/gdw, average) }\end{array}$ & $\begin{array}{l}\text { tremolite/actinolite } \\
\quad(\mathrm{ff} / \mathrm{gdw} \text {, average) }\end{array}$ & $\begin{array}{l}\text { edenite } \\
\text { (ff/gdw, } \\
\text { average) }\end{array}$ & $\begin{array}{l}\text { crocidolite } \\
\text { (ff/gdw, } \\
\text { average) }\end{array}$ & $\begin{array}{c}\text { grunerite } \\
\text { asbestos } \\
\text { (ff/gdw, } \\
\text { average) }\end{array}$ & $\begin{array}{c}\text { grunerite } \\
\text { (ff/gdw, } \\
\text { average) }\end{array}$ \\
\hline & $\begin{array}{c}\% \\
\mathrm{Bff}\end{array}$ & $\begin{array}{c}\% \\
\text { sff* }\end{array}$ & Bff & sff & Bff & Bff & Bff & sff \\
\hline LSV (58) & 94 & 6 & 44,610 & 3,048 & 0 & 1,123 & 2,066 & 0 \\
\hline USV (100) & 89 & 11 & 12,974 & 1,747 & 1,310 & 0 & 0 & 0 \\
\hline LV (83) & 90 & 10 & 13,102 & 1,497 & 168 & 0 & 1,080 & 180 \\
\hline VV (33) & 100 & 0 & 1,122 & 0 & 0 & 0 & 0 & 0 \\
\hline VC (29) & 65 & 35 & 1,031 & 556 & 0 & 0 & 0 & 0 \\
\hline AT (5) & 100 & 0 & 136 & 0 & 0 & 0 & 0 & 0 \\
\hline
\end{tabular}

Tab. 2 Average concentration (ff/gdw) of amphibole fibers differentiated, according to their chemical composition, size and source, in: tremolite/actinolite asbestos, tremolite/actinolite (non asbestos), edenite from Ns; crocidolite, grunerite asbestos and grunerite (non asbestos) from As

* percentage of samples where amphibole fibers are detected

** percentage of Bff and sff with respect to the total amphibole fibres 


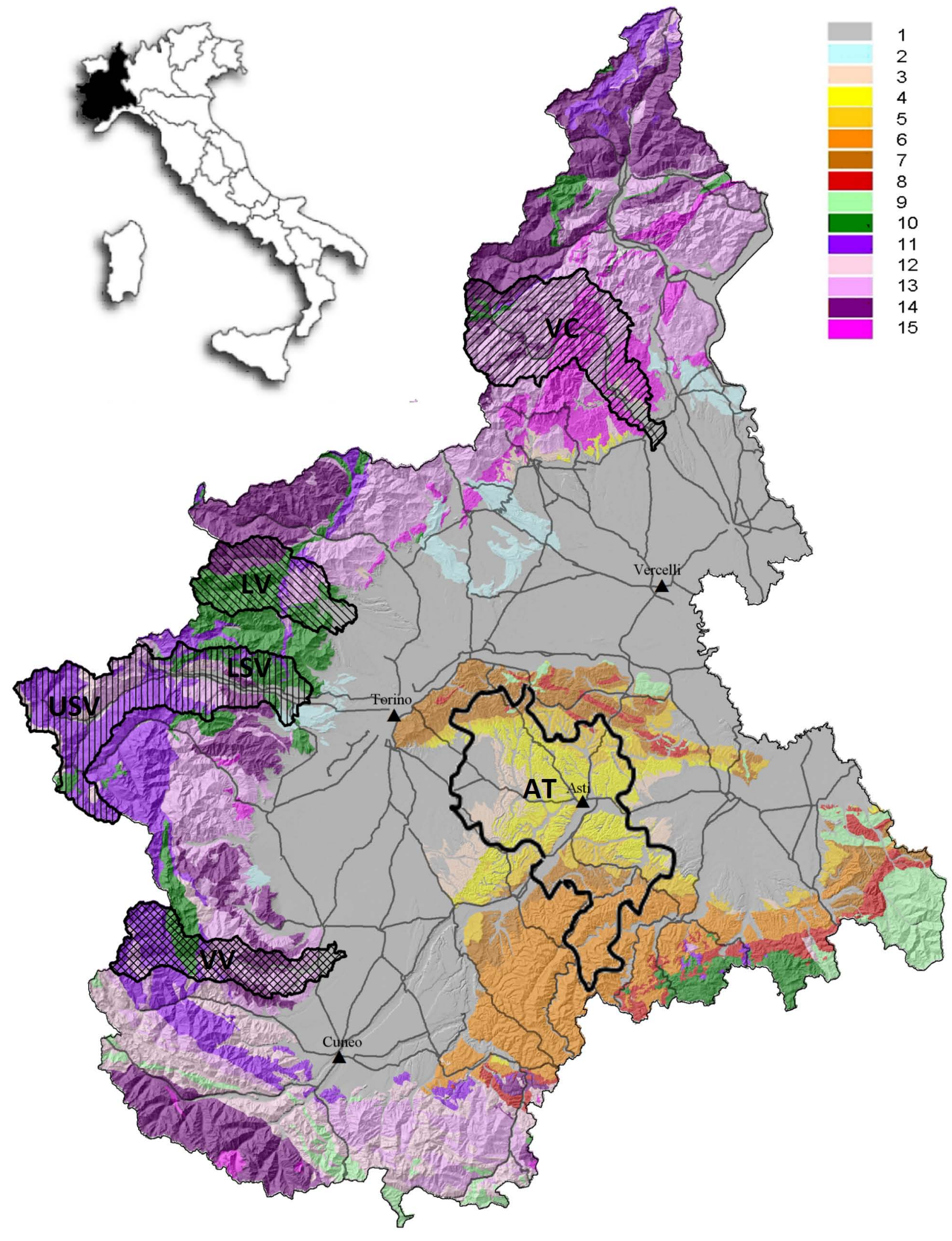

50

25

0 Kilometers 


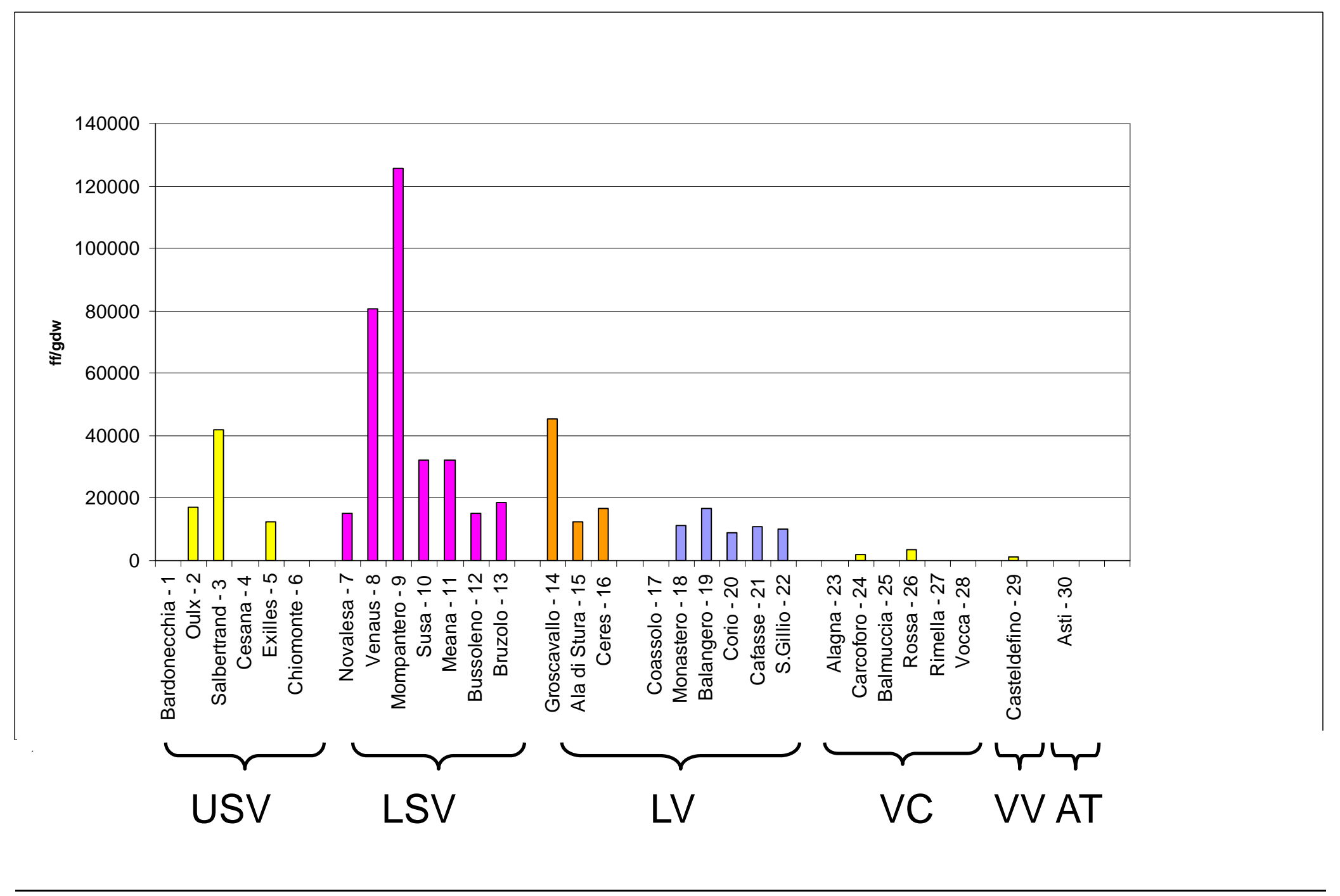



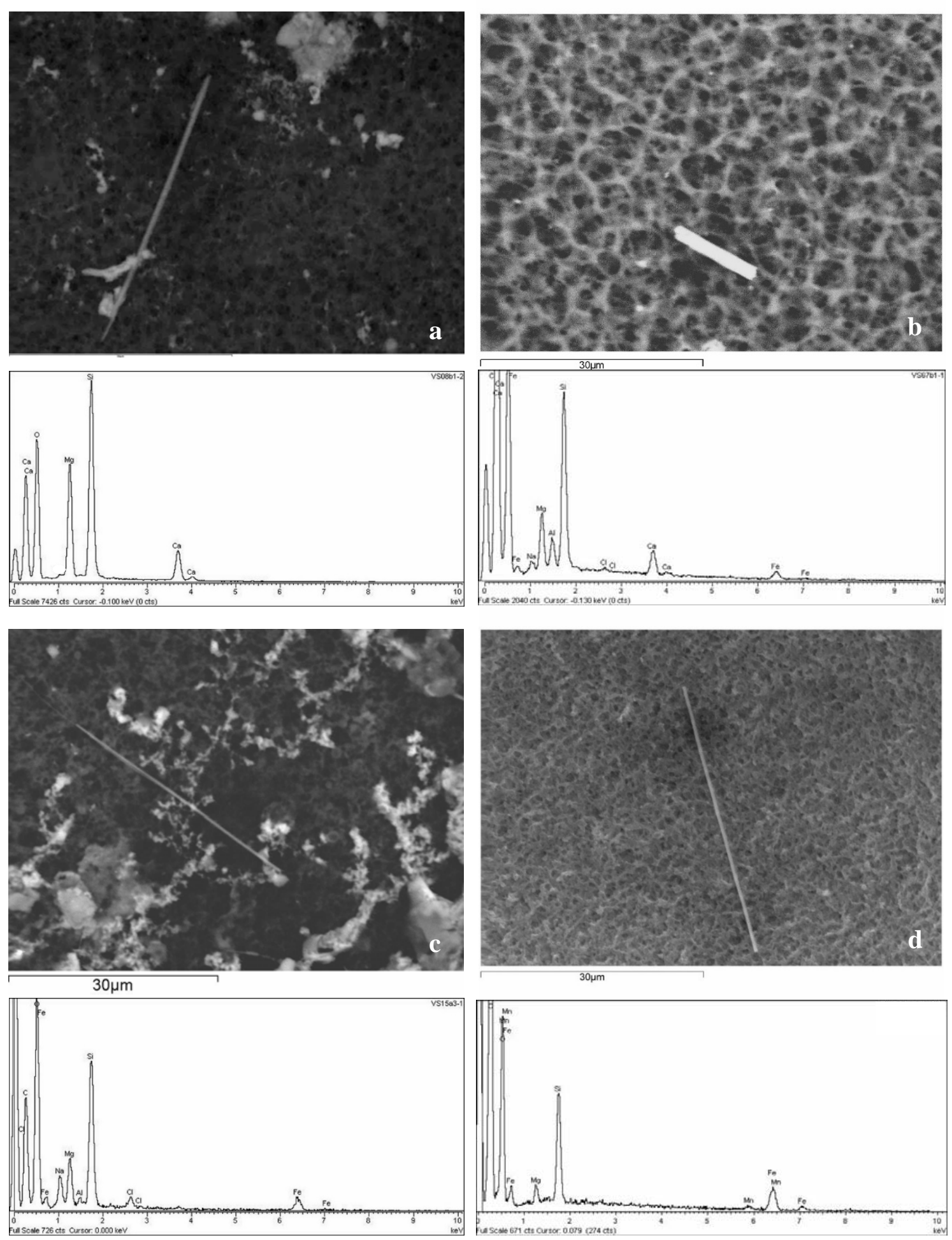